DOI 10.37882/2223-2982.2021.08.03

\title{
«ПЛОДАМИ ПОБЕДЫ БУДУТ ПОЛЬЗОВАТЬСЯ ОДИНАКОВО». К ВОПРОСУ ОБ ОБЩЕСТВЕННО-ПОЛИТИЧЕСКОЙ ДИСКУССИИ 1926 Г. О ПРИЧИНАХ И ХАРАКТЕРЕ ВОССТАНИЯ 1916 Г. В СРЕДНЕЙ АЗИИ
}

\section{"THE FRUITS OF VICTORY WILL BE USED EQUALLY." TO THE QUESTION OF THE PUBLIC AND POLITICAL DISCUSSION OF 1926 ABOUT THE REASONS AND CHARACTER OF THE 1916 UPRISING IN CENTRAL ASIA}

I. Vovk

D. Afanasiev

Summary: The article examines in detail the initial stage of the first sociopolitical discussion in the USSR on the causes and nature of the 1916 uprising in Turkestan. On the example of the analysis of reports and works of prominent social and political figures of the Soviet regime in Central Asia G.I. Broido and T.R. Ryskulov, an assessment of their ideas about the driving forces and deep causes of the 1916 uprising is given, which became a kind of intellectual basis for subsequent discussions of the $30 \mathrm{~s}$ of the twentieth century.

Keywords: discussion, reports, articles, national liberation movement, revolution, aliens, martial law, empire.
Вовк Игорь Валентинович

дочент, Орский гуманитарно-технологический институт (филиал) Оренбургского государственного университета, г. Орск opom@ogti.orsk.ru

Афанасьев Дмитрий Константинович учитель, МОАУ «Средняя общеобразовательная школа № 35 г. Орска», г. Орск jiva96@mail.ru

Аннотация: В статье подробно рассмотрен начальный этап первой общественно-политической дискуссии в СССР по вопросу о причинах и характере восстания 1916 г. в Туркестане. На примере анализа отчетов и работ видных общественно-политических деятелей советской власти в Средней Азии Г.И. Бройдо и Т.Р. Рыскулова дается оценка их представлений о движущих силах и глубинных причинах восстания 1916 г., которые стали своего рода интеллектуальными основами для последующих дискуссий 30-х годов XX века.

Ключевые слова: дискуссия, отчеты, статьи, национально-освободительное движение, революция, инородцы, военное положение, империя.
И нтерес к восстанию 1916 г. в Средней Азии в последнее десятилетие становится все более интенсивным, охватывая широкие круги исследователей не только в Российской Федерации, но и в целом ряде постсоветских государств (Казахстан, Таджикистан, Кыргызстан, Узбекистан). В некоторых случаях публикации на тему восстания далеки от стандартов научного исследования, а посвящены поиску «национальной идеи, которая непосредственно связана с проблемами 1916 г.» [3]. В этом случае на состояние научных исследований оказывают серьезное влияние следующие факторы: политическая элита; негативное воздействие со стороны прозападных и протурецких структур и ученых; деградация науки и академического сообщества; доминирование в обществе фолк-истории, которая опирается на локальную устную историю и художественную литературу $[2,376]$.

Тем не менее научные дискуссии по теме восстания 1916 г. становятся все более частым явлением, и их итогом являются серьезные научные монографии и сборни- ки межвузовских конференций. Интересно, что первые исследования о событиях среднеазиатского восстания 1916 г. появляются еще в 20-е гг. XX века, а в 1924-1926 гг. проходит первая научная дискуссия по вопросу о характере, причинах и движущих силах восстания. Зачинателями и участниками дискуссии были известные государственный и партийные деятели среднеазиатских советских республик. К их числу можно отнести, например, Бройдо Г.И. и Рыскулов Т.Р. Бройдо Г.И. в годы революции и гражданской войны являлся председателем Ташкентского Совета и в начале 20-х гг. был заместителем народного комиссара по делам национальностей РСФСР.

Рыскулов Т.Р. в 20-е гг. был председателем Совета народных комиссаров Туркестанской АССР и впоследствии представителем Коминтерна в Монголии. Именно он возглавлял комиссию ВЦИК по преобразованию Киргизской автономной области в автономную республику в 1926 г. 
Постепенно в дискуссию включаются не только видные партийные и государственные деятели и участники событий 1916 г., но и профессиональные историки Е. Федоров, В.Г. Некрасов-Клиодт, А.В. Шестаков и другие. Важным моментом в рассмотрении хронологических рамок дискуссии (1924-1932) являются представления руководителей советского государства о национальном вопросе, национализме и шовинизме в СССР.

«Период с 1919 г. по 1923 г. был посвящен выработке того, что именно может означать «национальное самоопределение» нерусских в контексте унитарного Советского государства» $[6,90]$.

В ходе ожесточенных дискуссий, доходивших до прямых столкновений оппонентов (например, в 1922 г. при рассмотрении так называемого «грузинского дела»), В.И. Лениным и И.В. Сталиным были выработаны важные теоретико-методические предпосылки разрешения так называемого «национального вопроса» на восточных окраинах СССР.

С одной стороны, руководители партии и советского государства считали, что максимальное развитие национального сознания есть важнейший этап на пути к новому интернациональному обществу бывших колониальных народов. Еще в годы Первой мировой войны В.И. Ленин писал, что «к неизбежному смешению наций человечество может прийти лишь через переходный период полного освобождения всех угнетенных наций» [4].

С другой стороны, большевистские руководители считали, что национализм угнетенных народов есть ответ на угнетение этих народов в составе Российской империи. При этом он мотивировался «исторически оправданным недоверием к великороссам» $[6,93]$. В.И. Ленин считал, что национализм бывших колониальных народов несет в себе «демократическое содержание» и его необходимо поддерживать. Национализм же «имперских» народов, в первую очередь, русских, непростителен [5]. Эти взгляды впоследствии легли в основу марксистко-ленинской концепции и национальном вопросе в СССР.

Дискуссия 1924-1926 гг. по поводу причин, движущих сил и характера восстания 1916 г. в Туркестане и Степном крае в определенной степени отражала характер общероссийской, а затем и общесоюзной дискуссии среди высшего руководства партии большевиков.

В 1924 г. в журнале «Новый Восток» Г.И. Бройдо публикует текст своих показаний, которые он дал в Ташкентской Судебной Палате прокурору Адамову 3 сентября 1916 г. Фактически это была первая работа по изучению и характеристике событий 1916 года. Уже в предисловии
Бройдо Г.И. пишет, что главная причина восстания «непосредственная деятельность власти, направленная на то, чтобы вызвать, провоцировать восстание для уничтожения человеческого материала Киргизии и для расчистки земли для новых колонизаций». Целью этого является подготовка «к изысканию «земельки» русскому мужику, который должен быть в результате поднять свой голос и оружие за землю» $[1,1-2]$. По мнению автора, царскому правительству нужно было «вырезать киргиз, спугнуть их в Китай и захватить новые земельные фонды» именно для того, чтобы решить аграрный вопрос в Центральной России в пользу «русского мужика».

Г.И. Бройдо достаточно подробно описывает особенность функционирования местной администрации в Джетысуйской области, а также структуру киргизского общества, в основе которой, по его словам, лежит «принцип партий», означающий не что иное как развитые родо-племенные отношения. Автор считает, что царская администрация очень искусно приспособилась к особенностям функционирования родовых отношений у киргизов, и именно это является одним из основных способов эксплуатации коренного населения. «В Семиречье чины администрации - члены «партий и получают мзду в большинстве случаев от главарей партий» $[1,15]$. Таким образом, именно коррупция, основанная на круговой поруке, является одной из глубинных причин восстания 1916 г.

Первая мировая война усугубила сложившуюся ситуацию. Высочайшее повеление Николая II о мобилизации на тыловые работы коренного населения Туркестана привело к тому, что «партийная борьба» на почве составления списков (реквизированных) привела к тому, что «громадное большинство рабочих определялось из партии «меньшинства» $[1,20]$. Таким образом, на тыловые работы отправлялись в основном те, кого не могли защитить родственники, слабо связанные с представителями царской администрации. Само восстание летаосени 1916 г., включая его причины и движущие силы Г.И.Бройдо рассматривает только на материалах по Джетысуйской области генерал-губернаторства, а также на основе своих личных впечатлений от пребывания там.

Часто Бройдо Г.И. называют автором так называемой «теории провокации» [8], в соответствии с которой восстание есть плод сознательных действий со стороны представителей царской администрации в Туркестане, «направленной на то, чтобы очистить земли для дальнейшей колонизаторской деятельности царизма [8]. Последовательно отрицая иные причины восстания в Туркестане (национальное угнетение, религиозные притеснения, антивоенное движение и т.д.), автор пишет, что «остается одно: восстание было результатом провокационной работы администрации, чтобы вырезать киргиз- 
ское население и очистить земли для дальнейшей колонизационной деятельности правительства. Нелепые приказы, ложные разъяснения чинов администрации, натравливание русских поселенцев, организация из них отрядов, безнаказанность массовых убийств - все это было основание к массовому «уничтожению» киргиз [1].

Показания Г.И. Бройдо и его последующие статьи стали своего рода «фундаментом» дискуссии, в которую вовлекались видные деятели революционного движения Казахстана и Кыргызстана.

Т.Р. Рыскулов, занимавший высокий пост третьего заместителя председателя Совета народных комиссаров РСФСР (1926-1937), стал автором очередного отчета «О восстании казахов и киргизов в 1916 г. Основные экономические и политические причины восстания [7, 46-122].

В 1916 г. Т. Рыскулов участвовал в восстании, и драматизм оценок этих событий ощущается в его работах. В одной из своих статей он определяет события 1916 г. как «национально-освободительную борьбу казахов и киргиз против пятидесятилетнего господства и гнета царского самодержавия, его насилия над народами Туркестана» [10].

В последующих работах [9] автор особо подчеркивает характер национального угнетения коренного населения края. Так, характеризуя распоряжения Военного министра по Туркестанскому краю от 8 июня 1916 г., Рыскулов Т. делает вывод, что привлечение к «мобилизации рабочих из среды инородческого населения» происходило из-за того, что «царское правительство усматривало в туземцах материал более покорный, чем русские крестьяне и рабочие, так сказать «дармовой», которым можно было распорядиться как угодно, не боясь их ропота и недовольства ...» $[9,5]$.

Очень подробно Рыскулов Т. характеризует приказы, связанные с введением военного положения в Туркестане, видя в них ущемление национального достоинства местного населения. Введение обязательных поклонов представителей коренного населения перед офицерами и чиновниками всех ведомств, запрет на продажу железнодорожных билетов «персам, киргизам, татарам и бухарским евреям» однозначно трактуется автором как проявление «великодержавного» шовинизма русских, хотя среди офицеров императорской армии и в полиции было большое количество выходцев с национальных окраин России.

Значимым объектом критики для Рыскулова является российская пресса, в частности популярные газеты «Туркестанские ведомости» и «Туркестанский Голос», в которых публиковались приказы и распоряжения царской администрации в регионе, в том числе посвященные мобилизации коренного населения для отправки на тыловые работы [11, 12]. Автор подробно цитирует самые «циничные», по его мнению, статьи и объявления и особо останавливается на статье «Акт справедливости», в которой рассматривались причины мобилизации коренного населения с точки зрения общегосударственных национально-патриотических интересов и имперской традиции управления Россией. По поводу необходимости привлечения к труду на фронте жителей Туркестана «сходились во мнении все колониальные верноподданные чиновники и русская буржуазия в Туркестане $[9,6]$.

Основное внимание в своих работах Рыскулов Т. уделяет экономическим и политическим причинам восстания 1916 г. в Средней Азии. Определяя набор «на тыловые работы туземцев» как повод для восстания, автор пытается рассмотреть предельно широко его исторические и культурные основания.

Рыскулов дает свою интерпретацию зарождающегося национально-освободительного движения в регионе, связывая его с «неустойчивым состоянием самой России, возникшим с мировой империалистической войной [9, 71]. Война изменила, по мнению автора, характер отношений между «метрополией и подчиненными ей окраинами, где среди инородцев постепенно зарождалась надежда, воспользовавшись благоприятной ситуацией после мировой войны, наконец скинуть гнет царской колониальной власти» $[9,72]$. «В составе бывшей Российской империи, - пишет Рыскулов, - этой «тюрьмы народов» Туркестан является той окраиной, которая больше чем остальные оказалась отсталой в культурном отношении и запечатлела на себе отпечаток специфических признаков колониальной зависимости» $[9,72]$.

Одной из важнейших причин «присутствия» России в Туркестане Рыскулов считает геополитические интересы в регионе. «В захватническом движении царской России «за Урал» Туркестан привлекал больше внимания царской администрации, прежде всего, как военно-стратегическая база, утвердившись на которой твердой ногой, можно было бы соперничать с Англией на Востоке и исполнить заветную мечту русских царей еще со времен Петра Великого о «завладении» богатейшей Индией...» [9, 72]. Таким образом автор помещает восстание 1916 г. в широкий контекст мировой политики, описываемой В.И. Лениным и И.В. Сталиным как «пробуждение Азии». По мнению Рыскулова, становлению национально-освободительного движения в Средней Азии способствовала переселенческая программа царского правительства, русская колонизация регионов Туркестана, «миссионерская политика, связанная с захватом школ инородцев» и т.п. $[9,73]$. 
В целом, подводя итог начальному этапу общественно-политической дискуссии 1926 г., касающейся причин, характера и движущих сил восстания 1916 г. можно сделать следующие выводы:

1. В работах Г.И. Бройдо и Т.Р. Рыскулова отчетливо просматриваются идеи о национальном угнетении коренного населения региона со стороны российской администрации. Этот фактор, по мнению авторов, является важнейшей причиной вос- стания в 1916 году.

2. Г.И. Бройдо и Т.Р. Рыскулов помещают движение 1916 г. в широкий контекст общеимперской и даже мировой политики. Это в свою очередь стимулирует последующих исследователей восстания 1916 г. к проработке идеи национально-освободительного движения в восточных, азиатских обществах.

\section{ЛИТЕРАТУРА}

1. Бройдо Г.И. Восстание киргиз в 1916 г.: (мое показание прокурору Ташкентской судебной палаты, данное 3-го сентября 1916 г.) / Г.И. Бройдо. М.: Научная ассоциация востоковедения при ЦИК СССР, 1925. - 28 с.

2. Восстания 1916 г. в Азиатской России: неизвестное 06 известном (К 100-летию Высочайшего повеления 25 июня 1916 г.): коллективная монография / ред.-сост.: Т.В. Котюкова. - М.: Русский импульс, 2017. - 528 с. - ISBN 978-5-90252588-2.

3. Какеев А.И. Восстание 1916 года: к проблеме историографии и источниковедения / А.И. Какеев // Вестник КРСУ. - 2015. - Т. 5. - С. 200.

4. Ленин В.И. Социалистическая революция и право наций на самоопределение / В.И. Ленин // Полное собрание сочинений - 5-е изд. - М.: Издательство политической литературы, 1967-1981 гг. - т. 27. - С. 256.

5. Ленин В.И. 0 праве наций на самоопределение / В.И. Ленин // Полное собрание сочинений - 5-е изд. - М.: Издательство политической литературы, 1967-1981 гг. - т. 25. - С. 277.

6. Мартин Т. Империя положительной деятельности // Государство наций: Империя и национальное строительство в эпоху Ленина и Сталина / под ред. Р.Г. Суни, Т. Мартина. - М.: Российская политическая энциклопедия (РОССПЭН), 2011. - С. 88-116. - ISBN 978-5-8243-1475-5.

7. Очерки революционного движения в Средней Азии: сборник статей Ф. Ходжаева, Е. Федорова, Т. Рыскулова, С. Гинзбурга. - М.: Науч. ассоциация востоковедения при ЦИК СССР, 1926. - 152 с.

8. Проблемы советской историографии восстания 1916 года в 20-30 гг. ХХ вв. / [Электронный ресурс]: - Режим доступа: https://ia-centr.ru/experts/iats-mgu/ problemy-sovetskoy-istoriografii-vosstaniya-1916-goda-v-20-30-gg-xx-vv/

9. Рыскулов Т.Р. Восстание туземцев Средней Азии в 1916 г. В 2 частях / Т.Р. Рыскулов. Кызыл-Орда: Гос. изд-во КССР, 1927. - 124 с.

10. Рыскулов Т.Р. Из истории борьбы за освобождение Востока/ Восстание киргиз Туркестана против царизма в 1916 г. // Новый Восток. - 1924 . - № 6.

11. Туркестанские ведомости. - 1916. - № 157. - 18 июля.

12. Туркестанский голос. - 1916. - № 158. - 20 июля.

○ Вовк Игорь Валентинович (opom@ogti.orsk.ru), Афанасьев Дмитрий Константинович (jiva96@mail.ru)

Журнал «Современная наука: актуальные проблемы теории и практики» 